\title{
The role of forests in regulating water: The Turkey Lakes Watershed case study
}

\author{
by N.W. Foster ${ }^{1,2}$, F.D. Beall and D.P. Kreutzweiser ${ }^{1}$
}

\begin{abstract}
Long-term experimental catchment studies, applied to relatively undisturbed ecosystems, provide reliable hydrologic data that are highly relevant to forest management decisions on water supply and quality. A number of large-scale, longterm catchment studies have been conducted in North America to examine these linkages and processes in support of watershed management decisions. Among these the Turkey Lakes Watershed (TLW), a rare example of a long-term fully integrated examination of the biology and chemistry of the atmosphere, forests, soils, streams, and lakes, is presented as a case study. Multi-agency, interdisciplinary research at the TLW, which has strong links nationally and internationally, has included hydrological studies, examination of landscape influences on nutrient export to surface waters, and impacts of catchment disturbance on water yield, nutrient flux, carbon cycling, and sedimentation in streams. Application of partial cut harvest systems in the TLW tolerant hardwood forest resulted in reduced runoff and improved water quality (sediment, nitrate and calcium concentrations) relative to clearcut harvest. Twenty years after the initiation of reductions in atmospheric $\mathrm{S}$ emissions losses of $\mathrm{SO}_{4}{ }^{2-}$ from some headwater basins remain high and there is little evidence of acidification recovery in TLW surface waters. The TLW research approach can be used globally to scientifically assess how natural and human actions affect the important services provided by forested watersheds. For example, TLW results have contributed to international policy on acid rain reductions and air quality agreements.
\end{abstract}

Key words: forest hydrology, water quality, hydrochemistry, forest disturbance, forest harvest, acid rain

\section{RÉSUMÉ}

Les études à long terme des bassins hydrographiques, effectuées sur des écosystèmes relativement intacts, fournissent des données hydrologiques fiables qui sont très pertinentes dans le cas de décisions d'aménagement forestier liées à l'approvisionnement en eau et à sa qualité. Plusieurs études à long terme et à grande échelle de bassins hydrographiques ont été menées en Amérique du Nord pour étudier ces relations et ces processus pouvant appuyer les décisions d'aménagement d'un bassin versant. Parmi ces études, le bassin versant des Turkey Lakes, un exemple unique d'une étude à long terme totalement intégrée de la biologie et de la chimie de l'atmosphère, des forêts, des sols, des ruisseaux et des lacs, est présenté à titre d'étude de cas. Une recherche interdisciplinaire des Turkey Lakes, impliquant plusieurs agences et ayant d'importantes ramifications nationales et internationales, comprenait des études hydrologiques, l'étude de l'influence du paysage sur l'exportation d'éléments nutritifs à la surface del'eau et les conséquences de la perturbation du bassin hydrographique en matière de rendement en eau, du flux des éléments nutritifs, du cycle du carbone et de la sédimentation dans les ruisseaux. L'utilisation d'un mode de récolte par coupe partielle dans un peuplement de feuillus tolérants des Turkey Lakes a engendré une réduction du débordement et une amélioration de la qual itéde l'eau (sédiments et concentrations de nitrate et de calcium) comparativement à une coupeà blanc. Vingt ans après le début de la réduction des émissions atmosphériques deS, les pertes en $\mathrm{SO}_{4}^{2-}$ dans certains bassins de tête demeurent élevées et il y a un peu de récupération en matière d'acidification des eaux de surface des Turkey Lakes. L'approche de recherche des Turkey Lakes peut être utilisée globalement pour évaluer scientifiquement comment les perturbations naturelles et humaines affectent les importants services rendus par les bassins versants boisés. À titre d'exemple, les résultats des Turkey Lakes ont contribué à des politiques internationales sur la réduction des pluies acides et à des ententes sur la qualité de l'air.

Mots clés : hydrologie forestière, qualité de l'eau, chimie de l'eau, perturbation forestière, récolte forestière, pluies acides

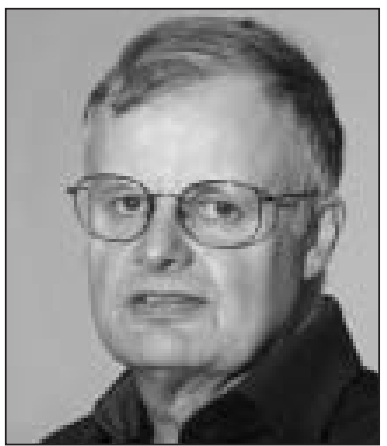

N.W. Foster

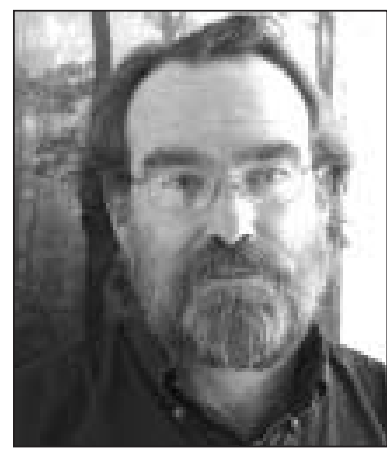

F.D. Beall

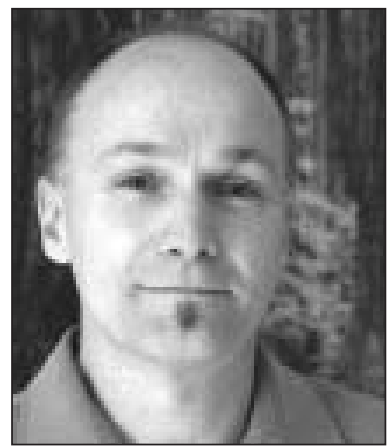

D.P. Kreutzweiser
${ }^{1}$ Natural Resources Canada Canadian Forest Service, 1219 Queen St. E., Sault Ste. Marie, Ontario P6A 2E5.

${ }^{2}$ Corresponding author. E-mail: nfoster@nrcan.gc.ca 


\section{Introduction}

A renewed focus on issues of water and watershed manage ment is occurring worldwide as part of the "International Year of Water Resources" in 2003. Increased concerns over diminishing renewable freshwater supplies have prompted global interest in watershed research and management. In some parts of the world, including Canada, much of the accessible freshwater supply is derived from forested watersheds. There is a growing international concern that shortages of fresh water and the increasing pollution of water bodies are limiting economic development in many countries (Sedell et al. 2000). The provision of abundant and safe drinking water must be a top priority of land use decisions. The most significant water quality problems resulting from unrestricted logging and land clearing are increases in sediment, nutrients, and temperature of first-order streams. Reliable hydrologic data and principles derived from catchment studies are highly relevant for the design and implementation of forest management practices that ensure the protection of aquatic ecosystems and water resources. The development of forest watershed management policies for the maintenance of freshwater supplies and aquatic habitats requires science based knowledge of land/water linkages and their underlying, hydrological, biogeochemical, and ecological processes.

Why is the provision of clean water from forested watersheds so important? The global economy (energy, transportation), quality of life, and cultural identity are highly dependent on forested watersheds and water resources. As a result of expanding human activity there will bean increased global demand for forests to provide clean water for a multiplicity of purposes, including agriculture, fisheries, and recreation. With $10 \%$ of the world's forests and $7 \%$ of the world's usable freshwater resources (much of it in forested areas), Canada's forests play critical roles in the regulation of stream flow and themaintenance of water quality. Watershed management in any nation must strike a balance between protection of water quality and quantity and the production of other values (e.g., timber, recreation, wildlife habitat).

Decisions on watershed management must be supported by both traditional and scientific knowledge of watershed functioning. Often watershed management standards in forestry are based on professional judgment because research has not defined the best management practices to integrate wood extraction with sustainable silviculture and the protection of other watershed values. It is imperative to understand the interaction of the hydrological cycle, geology, topography, soils, vegetation and the effects of human activities to design and implement safe, efficient land use practices. The catchment is a clearly defined topographical unit that provides a fundamental basis for hydrological evaluation. To ensure that development does not result in water contamination or shortages, water management programs must be developed worldwide to collect reliable hydrologic data from carefully designed catchment observations (Tajchman et al. 1997). Watershed management programs must emulate the results of research and monitoring that have successfully demonstrated how forests can be managed to sustain the supply of clean water for many needs. Synthesis of long-term research from catchment case studies is the foundation for a watershed management knowledge base, for translating sci- ence into practice and for developing policy to support sound management practices. We will use the Turkey Lakes Watershed (TLW) to illustrate the utility of experimental, multidisciplinary research catchments for assessing means of increasing water yields and maintaining water quality by studying differences in watershed runoff between undisturbed and managed and/or perturbed basins. For additional information on the TLW view theWeb site (www.tlws.ca).

\section{Study Area}

Water and soil sampling were conducted over a 20-year-period at the Turkey Lakes Watershed (TLW) in the Abitibi uplands of central Ontario ( $47^{\circ} 03^{\prime} \mathrm{N} ; 84^{\circ} 25^{\prime} \mathrm{W}$ ), Canada. The TLW is a headwater system with late-succession tolerant hardwood forest on steep terrain (10-30\%) in humid, midcontinental America, and relatively remote from industrial pollution sources. Four low elevation (weirs at 357 m-a.s.l.) first-order catchments, 4.5 to 68 ha in area were monitored for runoff, sediment, and the chemical composition of soil water and streams. The forest composition was mostly sugar maple (Acer saccharum Marsh) and a lesser component of yellow birch (Betula alleghaniensis Britton). Podzolic soils have developed in a stony, shallow $(\sim 0.5 \mathrm{~m})$, silty-loam ablation till, of mixed granite-basalt origin that covers bedrock or a coarser compacted basal till up to a meter in depth. Bedrock is predominantly Precambrian metamorphic basalt (greenstone) with minor occurrences of granite. The full variation in elevation ( 340 to $630 \mathrm{~m}$ ) at TLW was utilized by locating the 120-ha study area on the southwest side of Batchawana Mountain. The leeward location relative to Lake Superior strongly influences precipitation and water runoff. The mean annual precipitation is $1225 \mathrm{~mm}$, (annual snowfall equivalent of $325 \mathrm{~mm}$ ), and mean January and July regional temperatures $-11^{\circ} \mathrm{C}$ and $18^{\circ} \mathrm{C}$, respectively (Semkin et al. 2001).

\section{Methods}

The TLW has been, since late 1979 , the site of an interdisciplinary study of the impacts of the long-range transport of air pollutants on undisturbed Precambrian Shield forested catchments. In 1997 three lower elevation TLW catchments were harvested in a comparison of silvicultural systems, namely, single-tree selection, shelterwood, and clear-felling. The objective of the selection cut applied to catchment 33 (24 ha) was to remove an average of one-third of the basal area and leave a residual basal area of $18 \mathrm{~m}^{2} \mathrm{ha}^{-1}$ with a pre determined target representation in poles (10-24 cm dbh), and small $(26-40 \mathrm{~cm})$, medium $(42-48 \mathrm{~cm})$, and large $\left(50^{+}\right.$ $\mathrm{cm})$ sawlogs. A two-coup uniform shelterwood system was applied within catchment 34 (68 ha) with the initial cut to reduce canopy coverage to $50 \%$ of the original on average, with a second coup to be applied in ten years. A clearcut was applied to catchment 31 ( $4.5 \mathrm{ha}$ ) with thefelling and removal of all trees $>20 \mathrm{~cm}$ and the felling of all trees $>10 \mathrm{~cm}$. $M$ arked trees were harvested, with on-site delimbing, by feller buncher during July-August 1997. Catchment 32 ( $6.7 \mathrm{ha}$ ) was maintained as a control.

Soil water was sampled in pockets of undisturbed forest from 1996 to 1999 in each basin at depths of $30 \mathrm{~cm}$ below the soil surface, using 24 ceramic cups (Soil Moisture Equip. Corp.) under suction $(20 \mathrm{kPa})$. Cups were thoroughly 
Table 1. Mean annual sulphate fluxes (kg/ ha) in 1981 at the Turkey Lakes Watershed and mean five-year changes due to reductions in S02 emissions in North America

\begin{tabular}{lccccc}
\hline & & \multicolumn{3}{c}{ Period } \\
\cline { 3 - 6 } Location & Sulphate flux & $\mathbf{1 9 8 2 - 8 6}$ & $\mathbf{1 9 8 7 - 9 1}$ & $\mathbf{1 9 9 2 - 9 6}$ & $\mathbf{1 9 9 7 - 2 0 0 0}$ \\
\hline Precipitation & $\mathbf{1 9 8 1}$ & $-10 \%$ & $-27 \%$ & $-38 \%$ & $-49 \%$ \\
Stream 31 & 33.1 & $-31 \%$ & $-38 \%$ & $-41 \%$ & $-58 \%$ \\
Stream 32 & 54.4 & $+23 \%$ & $+10 \%$ & $-36 \%$ & $-50 \%$ \\
Stream 49 & 31.1 & $-12 \%$ & $-22 \%$ & $-36 \%$ & \\
\hline
\end{tabular}

cleaned and following installation were allowed to settle for two months, with 1 litre of soil water discarded, before sampling was initiated. Runoff from each catchment was continuously measured at a $120^{\circ} \mathrm{V}$-notch weir. Sampling for chemical analysis was monthly for soil water and daily during snowmelt and every two weeks thereafter for stream water.

Sulphate $\left(\mathrm{SO}_{4}{ }^{2-}\right)$, dissolved organic carbon (DOC) and nitrate $\left(\mathrm{NO}_{3}^{-}\right)$in solution were measured by a Technicon Autoanalyzer II system (sodium nitroprusside, acidified potassium persulphate methods and cadmium reduction methods, respectively). Highly coloured samples were analyzed for $\mathrm{SO}_{4}^{2-}$ by ion chromatography. Calcium $\left(\mathrm{Ca}^{2+}\right)$ in water was determined by atomic absorption spectroscopy. Wet-only deposition of $\mathrm{SO}_{4}{ }_{4}^{2-}$ in precipitation was collected 1 $\mathrm{km}$ from the TLW, at the Environment Canada, Canadian Air and Precipitation Monitoring Network (CapMoN) station (Algoma).

Procedures for collection, processing, and analyses of fine sediment samples are given in Kreutzweiser and Capell (2001). Briefly, fine sediments ( $<250 \mu \mathrm{m})$ were collected from streambeds with a $17.5-\mathrm{cm}$ diameter core sampler in which the substrates were stirred vigorously with a steel rod to suspend the fine particles. A manual bilge pump with a 2$\mathrm{mm}$ screened intake was used to pump 3.8 litres of water with suspended sediments through a 250- $\mu \mathrm{m}$ sieve into a collection bucket. The water and sediment that passed through the sieve were stirred vigorously and a $25-\mathrm{mL}$ subsample was drawn with a syringe and placed in a glass vial. The sediments were suction filtered on to $1.5-\mu \mathrm{m}$ glass fibre filters, dried at $60 \circ \mathrm{C}$ for 48 hours, weighed, then placed in a muffle furnace at $500^{\circ} \mathrm{C}$ for two hours, and weighed again to determine the organic (ash-free dry weight) and inorganic fractions. This provided a sediment size fraction of 1.5-250 $\mu \mathrm{m}$, and the stream bottom sediment concentration was expressed as $\mathrm{g} \mathrm{m}^{-2}$. Ten sediment samples were collected from each stream in early summer and late fall over a twoyear pre-harvest and three-year post-harvest period.

\section{Results and Discussion \\ Policy contributions}

Around the world, countries continue to develop institutional responses to combat air pollution threats to ecosystems and human health. Effects research conducted over the past 24 years at the TLW has developed and applied models simulating acidification effects on aquatic chemistry and biology (Lam et al. 1988); assessed the role of nitrogen-based pollutants in water and soil acidification (Foster and $\mathrm{H}$ azlett
2002), and examined the process, reversibility, and extent of chemical and biological recovery in streams and lakes (J effries et al. 2002). M oderate sensitivity to acid deposition was detected for forests and surface waters situated predominantly on metamorphic silicate bedrock (greenstone) overlain by thin glacial tills (M oayeri et al. 2001). Scientific findings from the TLW have reported on the effectiveness of domestic $\mathrm{SO}_{2}$ emission controls implemented in the $1980 \mathrm{~s}$ (Table 1), supported the negotiations that culminated in the Canada/US Air Quality Agreement (Canada/US 1983), and contributed to a national strategy for a post-2000, long-term domestic Acid Rain Program (Environ-ment Canada 1997). The latter report concludes that acidic deposition is a continuing threat to aquatic biota in eastern Canada and that further emission reductions are needed across eastern North America.

While some streams within the TLW have reduced exports of $\mathrm{S}$ proportional to reductions in atmospheric $\mathrm{S}$ input, others discharge $S$ in excess of or a surfeit of atmospheric inputs (Table 1). There is little evidence of acidification recovery in TLW surface waters (Jeffries et al. 2002), despite a $35 \%$ decrease, from the early 1980 s to the mid1990s, in atmospheric deposition of total S (Sirois et al. 2001). Dischargewater losses of $\mathrm{SO}_{4}{ }^{2-}$ from headwater basins remain high at TLW (Beall et al. 2001), and drought has delayed recovery by mobilizing $S$ stored in watershed soils (Jeffries et al. 2002), thereby slowing recovery of surface waters from acidification.

In 1998 the New England Governors and Eastern Canadian Premiers Conference formulated an Acid Rain Action Plan to address concern relating to soil acidification and forest health impacts. This action plan identified the mapping of forest sensitivity to acid deposition across eastern North America as a priority to enhance policy dialogue on further emission reductions. Biogeochemical data from the TLW and another 20 Canadian and 15 American plots and watersheds will be used along with spatial interpolation methods for mapping (Arp et al. 2001). By the completion of the project new technologies will have been developed and applied to integrate process studies and scale process information spatially and temporally. M aps will be developed that show the spatial distribution of sustainable acid deposition rates, wherethese rates are likely exceeded, and by how much.

\section{Forest management contributions}

Globally, policy makers continue to face important decisions relating to the effects of forest management practices 
on water quality and quantity. A key to improving the knowledge base on forest management impacts on aquatic systems is to incorporate paired-basin manipulative experiments and process studies into watershed research. Acquisition of this knowledge is relevant to the development of several Criteria and Indicators ( $C \& \mid$ ) that are being used in the Montréal Process to evaluate sustainable forestry in 12 countries with more that $70 \%$ of the boreal forest (Canadian Forest Service 1995). The operational relevance of research results must be improved in order to develop cost-effective techniques for monitoring water quality and meet reporting requirements under $C \& 1$. In a summary of research on forest disturbance impacts, Buttle et al. (2000) listed the TLW and seven other paired-basin studies that were distributed in four ecozones of Canada (Pacific Maritime, Montane Cordillera, Boreal Plain, and Boreal Shield). Additional examples of multidisciplinary research on the effects of land management on water quality are the U.S. Forest Service experimental forest catchments (e.g., Coweeta, Fernow, H.J. Andrews, and Hubbard Brook) (Henderson et al. 1978, Hornbeck et al. 1997, Tajchman et al. 1997).

At the TLW, a H arvesting Impacts Project included stemonly harvesting (clearcut), a shelterwood cut, a selection cut, and a control (no cut). The main objective with respect to water management was to quantify harvest intensity impact on water yield, quality and fauna in forest streams. Precipitation entering forest watersheds is partitioned into transpiration, water stored in the soil and runoff. Changes in annual water yield (runoff) due to clearcutting were indistinguishable from inter-annual variation in stream flow (Fig. 1a). However, growing season stream flow was increased, as evidenced by the stream not drying up in the three years post-harvest. Studies of the effects of clearcutting on stream flow in hardwood watersheds have shown there is proportionally a greater increase on growing season flows than on peak flows (Hornbeck et al. 1997, Swank et al. 2001). Beforefelling, theflux of inorganic N in TLW streams was 4-6 $\mathrm{kg} \mathrm{N} \mathrm{ha}^{-1} \mathrm{yr}^{-1}$. Dissolved inorganic $\mathrm{N}$ in soil water and streams was dominated by $\mathrm{NO}_{3}^{-}-\mathrm{N}$ before and after felling (Fig. 1, Table 2). Clearcutting produced maximum short-term increase in water yield $(73 \mathrm{~mm})$ and $\mathrm{Ca}^{2+}(28.8$ $\left.\mathrm{kg} \mathrm{ha}^{-1} \mathrm{yr}^{-1}\right)$ and $\mathrm{NO}_{3}-\mathrm{N}$ export $\left(36.6 \mathrm{~kg} \mathrm{ha}^{-1} \mathrm{yr}^{-1}\right)$ from the maple-dominated TLW catchments. Increases in ion export were similar in magnitude to increases reported elsewhere in tolerant mixed deciduous forest with coniferous inclusions (Jewett et al. 1995, M artin et al. 2000). The maximum increase in annual runoff (11\%) after clearcut harvest was less than those reported for other upland forests dominated by short growing seasons and shallow soils (Verry 1986, H ornbeck et al. 1997). Since yield increases disappear within three to 10 years, there are only limited possibilities for managing upland deciduous forests from the northeastern forests in the U.S. (Hornbeck et al. 1997) to the mid-continent (this study) to increase water supply.

The five-year cumulative leaching of $\mathrm{Ca}^{2+}$ from the soil ( $570 \mathrm{~kg} \mathrm{ha}^{-1}$ ) after clearcut logging was roughly equivalent to that removed in stem-only harvest. Total $\mathrm{Ca}^{2+}$ losses by harvesting and leaching were equivalent to the additional $\mathrm{Ca}^{2+}$ leaching produced by 39 years of acid deposition to the TLW as measured in the early 1980s. Selective harvest at up

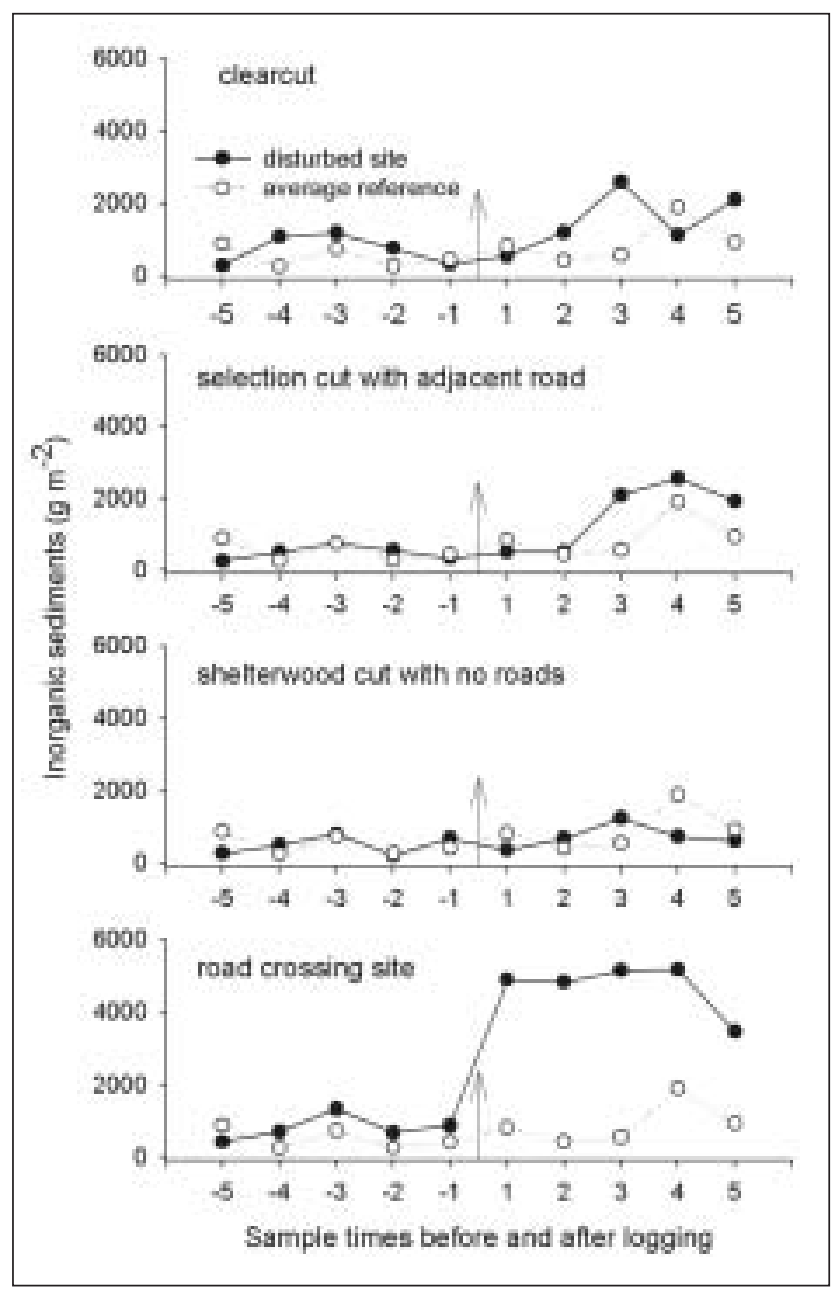

Fig 1 Annual yield of water (\% of precipitation), nitrate-N, calcium and dissolved organic carbon (DOC) from headwater catchments at the TLW. Treatment catchments were harvested in August/ September, 1997. Water years at TLW are defined as the period between J une 1 and May 31 of the following year.

to $50 \%$ removal mitigated most of the three year increases in runoff $\mathrm{NO}_{3}{ }^{-}, \mathrm{Ca}^{2+}$, and sedimentation that were produced in streams by clearcut logging (Fig. 1; 2). Gradualremoval harvesting operations offered greater protection of soils and natural regeneration and thereby increased protection of water quality. In contrast to long-lasting impacts of other land use changes, a return to pre-harvest levels in headwater streams was observed on all treatments for nitrate and calcium concentrations three years after harvest. The magnitude and duration of impacts on secondary and tertiary streams can be controlled by the timing, size, and dispersion of harvesting within a watershed.

Soils, especially those on steeper slopes, are sensitive to disturbance and mismanagement of land because they are prone to erosion. Commercial forestry operations (especially the roads associated with these practices) within watersheds can result in changes in water quality due to increased silt deposition (Waters 1995). In the TLW Harvesting Impacts Project, fine sediment deposition in streams was measured across the gradient of harvesting intensity 


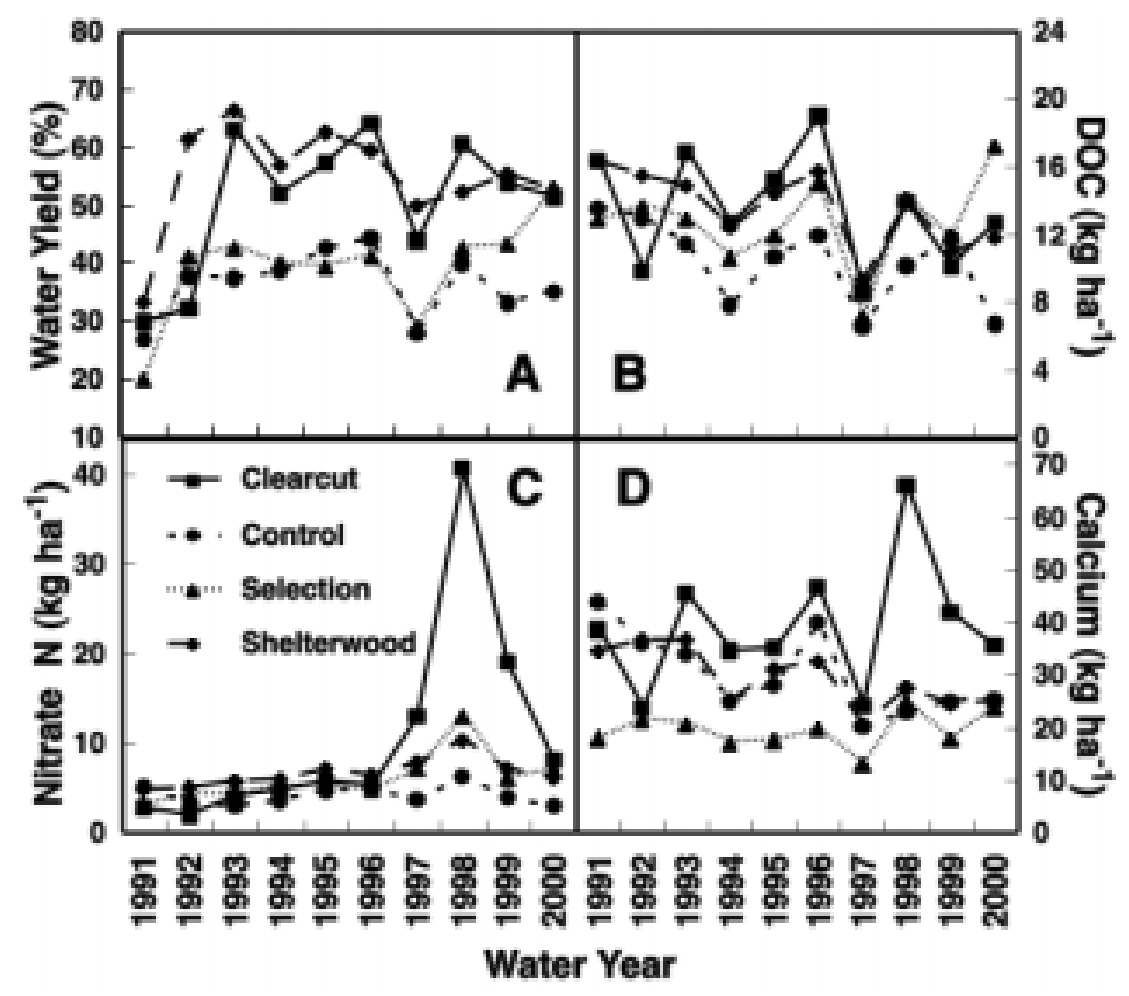

Fig. 2 Mean deposition (g m-2) of fine inorganic sediments (1.5-250 um) in streams of TLW logged catchments and at a logging-road crossing site before and after the logging activity, and in comparison to the average sediment deposition in three undisturbed reference streams. Arrows indicate the time of logging.

tial for linking terrestrial nutrient exports to surface water response in high relief catchments (Hazlett and Foster 2002). Natural variations in $\mathrm{N}$ export among catchments within the TLW have been documented and the processes that lead to these variations have been explored (Creed and Band 1998). For greater detail on TLW catchment characteristics and scientific findings see the Canadian Journal of Fisheries and Aquatic Sciences, 1988, vol. 45, Suppl.1, pages 1-178, Ecosystems, 2001, vol. 4, pages 501-567, and Water, Air, and Soil Pollution: Focus, 2002, vol. 2, pages 1-168.

\section{Summary and Conclusions}

Decisions made now and in the next decade are immensely important with respect to the global protection and sound management of forested watersheds to provide clean water for many purposes to future generations. The TLW is an example, one of many in North America, where recent advances in the understanding of natural processes and human impacts on services provided by experimental catchments have contributed to international policies and the adoption of sustainable watershed management. Watershed research and monitoring at the TLW and other eastern deciduous forests has demonstrated that there are limited opportunities for managing upland deciduous temperate forests to increase water yields for many purposes. Nevertheless, short-term post-harvest increases in $\mathrm{N}$ export

\section{Acknowledgements}

represented a significant input to surface waters at the TLW. Selective harvesting at up to $50 \%$ removal mitigated most of the three year increase in $\mathrm{NO}_{3}{ }^{-}, \mathrm{Ca}^{2+}$, and sedimentation that were produced in streams by clearcut logging at the TLW. Acidification effects of atmospheric $\mathrm{N}$ and $\mathrm{S}$ on aquatic chemistry and biology and the slow process of recovery in streams and lakes at the TLW in response to reductions in $\mathrm{SO}_{2}$ emissions across North America have been reported.

Canada is a world leader in producing and exporting forest science and technology. In a global context future land use decisions for the millions of people living in forested watersheds and down-stream areas may benefit from the sound scientific information derived from catchment research in Canada. We recognize, however, that forest demands, management and needs differ around the world. The transfer of environmentally sound science to other countries can be used to stimulate domestic dialogue on forest management decisions. Dissemination will help ensure that new projects can benefit from the experiences learned and avoid duplication of effort. There is a need for a more coordinated international effort for communicating information on the management of freshwater availability.

We thank Scott Capell, Sharon Gibbs, Laura H awdon, Linda Irwin, Wayne Johns, Don Kurylo, Doug Tribe, Tom Weldon and numerous students for technical assistance. We thank Robert Vet of the M eteorological Service of Canada for the $\mathrm{SO}_{4}{ }^{2-}$ wet deposition data. Comments on an earlier draft of the manuscript by Bill Meades and David Winston and an anonymous referee are also gratefully acknowledged. Financial support was provided by Natural Resources Canada - Canadian Forest Service.

\section{References}

Arp, P.A., W. Leger, M.H. Moayeri and J.E. Hurley. 2001. Methods for mapping forest sensitivity to acid deposition for northeastern North America. Ecosystem Health 7: 35- 47.

Beall, F.D., R.G. Semkin, and D. S. Jeffries. 2001. Trends in the output of first-order basins at Turkey lakes watershed, 1982-1996. Ecosystems 4: 514-526.

Buttle, J.M., I.F. Creed, and J.W. Pomeroy. 2000. Advances in Canadian forest hydrology, 1995-1998. Hydrol. Process 14: 1551-1578. 
Table 2. Pre-harvest mean annual soil water $\mathrm{NO}_{3}{ }^{-}$concentrations (ueqL ${ }^{-1}$ ) at the Turkey Lakes Watershed and mean annual changes due to different intensities of harvest

\begin{tabular}{lccrr}
\hline Year & Control & Clearcut & Selection & Shelterwood \\
\hline Pre-harvest & 112 & 93 & 137 & 161 \\
Post-harvest Year 1 & $-45 \%$ & $+118 \%$ & $+26 \%$ & $+30 \%$ \\
Post-harvest Year 2 & $-71 \%$ & $+475 \%$ & $+29 \%$ & $+34 \%$ \\
Post-harvest Year 3 & $+29 \%$ & $+29 \%$ & $-34 \%$ & $-32 \%$ \\
\hline
\end{tabular}

${ }^{1}$ Natural Resources Canada - Canadian Forest Service, 1219 Queen St. E., Sault Ste. Marie, Ontario P6A 2E5.

${ }^{2}$ Corresponding author. E-mail: nfoster@nrcan.gc.ca

(Kreutzweiser and Capell 2001), but see also an erratum, Kreutzweiser and Capell 2002). Clearcut harvesting caused significant increases in sediment deposition as a result of heavy ground disturbance and channelled flow paths from skidder activity in riparian areas. Sediment increases at other sites were attributable to road construction and maintenance, underscoring the need for designing and implementing effective sediment control strategies for road building in forest watersheds. At the shelterwood site (about 50\% removal) where roads were not a factor, no measurable increases in sediment deposition were detected even in the absence of protective buffer zones (Fig. 2). The TLW results demonstrate that selective hardwood harvesting at up to $50 \%$ removal can be conducted without increasing sediment inputs to streams by following best management practices and careful skid trail orientation. This science-based information contributes to the development of forest management guidelines for the protection of water resources in boreal and north temperate countries. Would other ecosystems respond similarly to a common disturbance such as cutting? Results generally are considered site-specific and may vary with energy and water balances, forest cover (age, species combinations), and soil conditions (soil texture, depth, stoniness), thereby influencing how broadly watershed research results can be interpreted and applied.

\section{Sustainability of watershed services}

The validity and generality of a single watershed study must be assessed relative to results from many such studies (Henderson et al. 1978). International inter-site comparisons between watersheds are one of the most valuable approaches that can be used to test hypotheses and to advance knowledge on how anthropogenic as well as natural factors influence forested watersheds. Such an approach may involve the application of a standardized experiment with a common set of measurements. An example is the Integrated Forestry Study, an international interdisciplinary study of nutrient transfer processes linking the atmosphere, living plants and animals, soil and soil water (Electric Power Research Institute 1986). Atmospheric acid inputs and their impacts on nutrient movement to ground and surface waters were quantified simultaneously across a range of climatic, vegetation, and soil conditions across $N$ orth America (including TLW) and Norway during 1986-89. An acrosssite comparison revealed that retention of atmospheric $\mathbf{N}$ was amongst the lowest and $\mathrm{N}$ discharge as $\mathrm{NO}_{3}{ }^{-}$from the soil the highest in TLW soils (Johnson and Lindberg 1992). Such comparisons foster interdisciplinary collaboration between scientists and can become a focal point for communicating information about water quality issues globally.

Alternatively, comparisons may take the form of sharing perspectives and results with others involved in similar research and the development of larger scale, more comprehensive research projects. An example is the Northeastern Ecosystem Research Cooperative (NERC), which supports research on watersheds across the eastern Canadian provinces and New England states. The TLW is one of 30 partners in the NERC with sites from an area with an underlying similarity in vegetation, soils, and climate. The collaboration takes the form of (1) sharing data and results, (2) developing regional data bases, (3) initiating joint research projects, (4) analysis and synthesis of regional environmental issues, and (5) increasing communication among researchers, resource managers and policy-makers (NERC 2000). The focus of the cooperative is on the health of the forest and aquatic ecosystems in the region. The primary scientific issues to be addressed involve hydrological and biogeochemical processes in forested ecosystems and surface waters.

Changes in watersheds can increase or decrease their capacity to contribute to human needs. Long-term records from the relatively undisturbed TLW have revealed much about natural rates of change in surface water quality and quantity, and about aquatic and terrestrial biology. A certain amount of change is "normal" or "acceptable" since forests, streams and lakes are continually exposed to natural (pests, pathogens, drought, flooding, windstorms, ice storms) and anthropogenic (air pollution, climate change) disturbances. For example, at the TLW the average annual water yield (percentage of annual precipitation) declined and the proportion of runoff occurring in different seasons changed between 1982 and 1996 (Beall et al. 2001). Likewise, a longterm examination of a fish community at the TLW in the absence of experimental perturbation has revealed declines in species in response to natural shifts at the community level (Smokorowski and Kelso 2002).

In Canada, fire and insect infestations are the dominant stand-renewing agents for forests in many of the nine distinct terrestrial ecozones. There are dramatic differences in hydrological and hydrochemical processes among these ecozones (Buttle et al. 2000). The whole-ecosystem investigative approach (Morrison et al.1999), which was initiated at the TLW in 1980, has resulted in increased understanding of the functioning and linkages between terrestrial and aquatic ecosystems. The prediction of water movement and soil development variation with topographic position is essen- 
Canada/US 1983. M emorandum of intent on transboundary air pollution. Report of the Impact Assessment Working Group I, Section 3-Aquatic Effects. 259 p.

Canadian Forest Service. 1995. Criteria and indicators for the conservation and sustainable management of temperate and boreal forests. The M ontreal Process. Can.For. Serv., Hull, QC. 28 p.

Creed, I.F., and L.E. Band. 1998. Exploring functional similarity in the export of nitrate $\mathrm{N}$ from forested catchments: a mechanisticmodeling approach. Water Resour. Res. 34: 3079-3093.

Electric Power Research Institute. 1986. Integrated Forestry Study. Tech. Brief, Electric Power Res. Inst., Palo Alto, CA. 4 p. Environment Canada. 1997. 1997 Canadian acid rain assessment. Vol.3. The effects on Canada's lakes, rivers, and wetlands. D.S. Jeffries (ed.). Supply and Services Canada, Ottawa.

Foster, N.W. and P.W. H azlett. 2002. Trends in water chemistry in a maple forest on a steep slope. Water, Air, Soil Pollut.: Focus 2: 23-36.

Hazlett, P.W., and N.W. Foster. 2002. Topographic controls of nitrogen, sulfur, and carbon transport from a tolerant hardwood hillslope. Water, Air, Soil Pollut: Focus 2: 63-80.

Henderson, G.S., W.T. Swank, J.B. Waide, and C.C. Grier. 1978. Nutrient budgets of Appalachian and Cascade region watersheds: A comparison. Forest Sci. 24: 385-397.

Hornbeck, J.W., C.W. Martin, and C. Eager. 1997. Summary of water yield experiments at Hubbard Brook Experimental Forest, New Hampshire. Can. J. For. Res.27: 2043-2052.

Jeffries, D.S., R.G. Semkin, F.D. Beall, and J. Franklyn. 2002. Temporal trends in water chemistry in the Turkey Lakes Watershed, Ontario, Canada, 1982-1999. Water, Air, Soil Pollut. Focus 2: 5-22.

Jewett, K., D. Daugharty, H.H. Krause, and P.A. Arp. 1995. Watershed responses to clearcutting: Effects on soil Solutions and stream water discharge in central New Brunswick. Can. J. Soil Sci. 75: 475-490.

Johnson, D.W. and S.E. Lindberg (eds.). 1992. Atmospheric Deposition and Forest Nutrient Cycling. Ecol. Studies 91. SpringerVerlag, New York, NY. 707 p.

Kreutzweiser, D.P. and S.S. Capell. 2001. Fine sediment deposition in streams after selective forest harvesting without riparian buffers. Can. J. For. Res. 31: 2134-2142.

Kreutzweiser, D.P. and S.S. Capell. 2002. Erratum: Fine sediment deposition in streams after selective forest harvesting without riparian buffers. Can. J. For. Res. 32: 1108.
Lam, D.C.L., A.G. Bobba, D.S. Jeffries, and D. Craig. 1988. M odelling stream chemistry for the Turkey Lakes Watershed: comparison with 1981-84 data. Can. J. Fish. Aquat. Sci. 45 (Suppl. 1): 72-80.

Martin, C.W., J.W. Hornbeck, G.E. Likens, and D.C. Buso. 2000. Impacts of intensive harvesting on hydrology and nutrient dynamics of northern hardwood forest. Can. J. Fish. Aquat. Sci. 57 (Suppl. 2): 19-29.

Moayeri, M., F-R. Meng, P.A. Arp, and N.W. Foster. 2001. Evaluating critical soil acidification loads and exceedances for a deciduous forest at the Turkey Lakes Watershed. Ecosystems. 4: 555-567.

Morrison, I.K., D. A. Cameron, N.W. Foster and A. Groot. 1999. Forest Research at the Turkey Lakes Watershed. For. Chron. 75: 395-399.

NERC. 2000. N ortheastern Ecosystem Research Cooperative. Draft Prospectus.

Sedell, J., M. Sharpe, D. Apple, M. Copenhagen, and M. Furniss. 2000. Water and the Forest Service. USDA For. Serv., Washington Office, FS-660. 26 p.

Semkin, R.G., D.S. Jeffries, R. Neureuthrer, G. Lahaie, F. Norouzian, and J. Franklyn. 2001. Summary of hydrological and meteorological measurements in the Turkey Lakes Watershed, Algoma, Ontario, 1980-1999. Environment Canada, National Water Research Institute Contribution N 0. 01-192. 42 p.

Sirois, A., R. Vet, and D. MacTavish. 2001. Atmospheric deposition to the Turkey Lakes Watershed: Temporal variations and characteristics. Ecosystems 4: 503-513.

Smokorowski, K.E. and J.R.M. Kelso. 2002. Trends in fish community structure, biomass, and production in three Algoma, Ontario, lakes. Water, Air, Soil Pollut.: Focus. 2: 129-150.

Swank, W.T., J.M. Vose, and K.J. Elliot. 2001. Long-term hydrologic and water quality responses following commercial clearcutting of mixed hardwoods on a southern Appalachian catchment. For. Ecol. M anage. 143: 163-178.

Tajchman, S.J., H. Fu, and J.N. Kochenderfer. 1997. Water and energy balance of a forested Appalachian watershed. Agric. For. Meteorol. 84: 61-68.

Verry, E.S. 1986. Forest harvesting and water; The Lakes States Experience. Water Resources Bulletin 22: 1039-1047.

Waters, T.F. 1995. Sediment in streams: sources, biological effects, and control. American Fisheries Society, Bethesda, M aryland. 251 p. 